\title{
CORRELATION OF ANTIOXIDANT AND ANTIPROLIFERATIVE ACTIVITY OF AMLA AND GINGER
}

\author{
SAFEENA KULSUM ${ }^{1,2}$, AMRITHA SURESH ${ }^{2}$, ALKA MEHTA ${ }^{1}$
}

${ }^{1}$ Department of Medical Biotechnology, School of Biosciences and Technology, Vellore Institute of Technology, Vellore - 632 014, Tamil Nadu, India. ${ }^{2}$ Integrated Head and Neck Oncology Research Program, Mazumdar Shaw Centre for Translational Research, \#258/A, $8^{\text {th }}$ Floor, A-Block, Mazumdar Shaw Medical Centre, Narayana Health, Bommasandra Industrial Area, Anekal Taluk, Bengaluru - 560099 , Karnataka, India. Email: alkamehta@vit.ac.in

Received: 20 March 2018, Revised and Accepted: 02 May 2018

\section{ABSTRACT}

Objective: Our study focused on evaluating the anticancer property of ascorbic acid and aqueous extract of amla and ginger.

Methods: Antioxidant capacity of ascorbic acid, aqueous extract of amla, and ginger was obtained by 2,2-diphenyl-1-picrylhydrazyl method and total antioxidant capacity (TAC). Vero cell line, PA-1, Cal-27, Cal-27 CisR, and DysMSCTR16 cell lines were treated with antioxidants to evaluate its antiproliferative property using 3-(4,5-dimethylthiazol-2-yl)-2,5-diphenyltetrazolium bromide assay. Colony and spheroid formation assays were also carried out in the presence of extracts to assess its role in anticancer stem cell activity.

Results: Two volumes of amla $5 \mu \mathrm{l}(\sim 0.016 \mathrm{~g})$ and $25 \mu \mathrm{l}(\sim 0.08 \mathrm{~g})$ and ginger $5 \mu \mathrm{l}(\sim 0.02 \mathrm{~g})$ and $25 \mu \mathrm{l}(\sim 0.1$ g) showed TAC activity equivalent to $0.25 \mathrm{mM}$ and $2 \mathrm{mM}$ ascorbic acid, respectively. Amla and ascorbic acid showed significant antiproliferative property in normal (Vero) $\mathrm{p}=0.05$, cancer (PA-1, Cal-27) p=0.005, and resistant (Cal-27 CisR) p=0.05 cell lines and ginger extract in Vero and Cal-27 cell lines ( $\mathrm{p}=0.05$ ). In PA-1 and Cal-27 CisR cell line, ginger extract showed proliferative activity $(\mathrm{p}=0.005)$. Antioxidants showed no antiproliferative activity in DysMSCTR16 cells. Amla extract and ascorbic acid showed significant inhibitory effect on spheroid ( $\mathrm{p}=0.005)$ and colony formation capacity ( $\mathrm{p}=0.0005)$ among dysplastic, cancer, and resistant cell lines. Ginger showed inhibitory effect $(\mathrm{p}=0.05)$ only in colony formation capacity.

Conclusion: Overall, we found a strong correlation between antioxidant and antiproliferative activity of ascorbic acid, amla, and ginger. Amla and ascorbic acid proved to be effective in controlling cell proliferation and self-renewal properties of cancer cells. However, ginger was found to have selective and less antiproliferative effect in comparison to amla.

Keyword: Amla, Ginger aqueous extract, Cancer progression, Cancer stem cells, Antioxidant-induced cell death

(C) 2018 The Authors. Published by Innovare Academic Sciences Pvt Ltd. This is an open access article under the CC BY license (http://creativecommons. org/licenses/by/4. 0/) DOI: http://dx.doi.org/10.22159/ajpcr.2018.v11i8.26073

\section{INTRODUCTION}

Amla, Indian gooseberry (Phyllanthus emblica officinalis) extracts, has been used in traditional medicine to treat symptoms ranging from constipation to cancer treatment for centuries in the Indian system of medicine [1]. E. officinalis has been shown to be a potent free radical scavenging agent, thereby preventing carcinogenesis and mutagenesis. A dose of $100 \mathrm{mg} / \mathrm{kg}$ body weight has shown to reduce the incidence of tumor by approximately $60 \%[2,3]$. Ginger (Zingiber officinale Roscoe) is also another natural dietary component generally used in complementary and alternative medicine (CAM). Various ginger and ginger leaf extracts have been reported positive response in controlling cancer proliferation [4]. Various components of ginger such as gingerols, paradols, shogaols, and gingerones have shown antioxidant, anti-inflammatory, anticancer, and antiangiogenic property [5]. Many studies showed its beneficial effect in lung, ovarian, colorectal, and gastric cancer [6-8]. In addition, dietary supplements containing ascorbic acid, lysine, proline, and green tea extracts are known to reduce the tumor growth in vivo studies [9-12]. Micromolar concentration of extracellular Vitamin C kills cancer cells but not normal cells in an $\mathrm{H}_{2} \mathrm{O}_{2}$-dependent manner [13].

Pro-oxidants are chemicals that induce oxidative stress, either by generating reactive oxygen species or by inhibiting antioxidant systems [14]. Oxidative stress in cancer cells is, however, a dual-edged sword and many cancer therapies rely on using an additional oxidative stressor to selectively drive cancer cells into programmed cell death. The high level of intrinsic oxidative stress expressed by many cancer cells has often been called the "Achilles' heel" of cancer [15]. Many exogenous antioxidants such as Vitamin E (tocopherols and tocotrienols), Vitamin C, green tea polyphenols, beta-carotene, and curcumin are individually as well as in combination have been known for their potential roles in CAM approaches to cancer prevention and treatment $[16,17]$. For public health professionals, the question of whether or not antioxidants have a safe chemopreventive role is central: It is clearly much more effective to prevent cancer than deal with its consequences including the damaging side effects of many chemotherapeutics. However, evidence is lacking for the effectiveness of most CAM therapies for cancer [18]. In parallel, cancer stem cells (CSCs) have been implicated in cancer progression, recurrence, and thereby poor prognosis due to their inherent quiescence and drug-resistant properties $[19,20]$. The role of CSCs in carcinogenesis has been investigated with multiple concepts proposed to explain their possible role in initiation of the tumorigenic process, subsequent field cancerization, and recurrence [21].

In this study, we investigate the antioxidant capacity of crude aqueous extracts of amla and ginger in comparison with ascorbic acid and study their effect on CSC in cell lines representing different stages of cancer progression. Normal, dysplastic, squamous cancer cells, and resistant cell lines, with different percentage of CSC population [22,23], were evaluated for the response of antioxidants from the extracts of amla and ginger. 


\section{METHODS}

\section{Preparation of plant extracts}

Ginger extract

Fresh aqueous ginger extract $(5 \mathrm{~mL})$ was prepared from $20 \mathrm{~g}$ of fresh ginger. Briefly, skin peeled ginger was grated and boiled in deionized water for $5 \mathrm{~min}$ and juice was squeezed under sterilized condition. After extraction, the juice was filtered through Whatman filter paper (\#Z146374-100EA, Sigma-Aldrich, USA). Sterility check was done by streaking the extract on nutrient agar plate for 3 days. It was stored in sterilized glass container at $4^{\circ} \mathrm{C}$ until used $(5 \mu \mathrm{l}$ of extract was approximately equivalent to $0.02 \mathrm{~g}$ of fresh ginger).

\section{Amla extract}

For aqueous extract, surface sterilized amla was peeled, grated, and squeezed with multilayered muslin cloth followed by filtration through Whatman paper-1 under sterilized conditions. Sterility check was done by streaking the extract on nutrient agar plate for 3 days. The extract was stored in sterilized glass container at $4^{\circ} \mathrm{C}$ until used. $6 \mathrm{~mL}$ of fresh amla extract was obtained from $20 \mathrm{~g}$ of fresh amla $(5 \mu \mathrm{l}$ extract was approximately equivalent to $0.016 \mathrm{~g}$ of amla).

\section{Antioxidant activity test \\ Determination of total antioxidant capacity (TAC)}

The antioxidant activity of the extract was evaluated by the phosphormolybdenum method according to the procedure describe by Prieto et al. [24]. The assay is based on the reduction of Mo (VI)-Mo (V) by the extract and subsequent formation of a green phosphate/Mo (V) complex at acid $\mathrm{pH}$. Fresh extracts of amla and ginger of varying amount $(5-100 \mu \mathrm{l})$ made to $0.3 \mathrm{~mL}$ with water was combined with $3 \mathrm{~mL}$ of reagent solution $(0.6 \mathrm{M}$ sulfuric acid, $28 \mathrm{mM}$ sodium phosphate, and $4 \mathrm{mM}$ ammonium molybdate). Methanol $(0.3 \mathrm{~mL})$ in place of extract is used as the blank. Tubes containing the reaction solution were incubated at $95^{\circ} \mathrm{C}$ for $90 \mathrm{~min}$. Then, the absorbance of the solution was measured at $695 \mathrm{~nm}$ using spectrophotometer (UV-1800, Shimadzu UV-Spectrometer) against blank after cooling to room temperature. The antioxidant activity is expressed as the number of g equivalents of ascorbic acid. Experiments were performed in triplicates.

\section{Radical scavenging activity}

The free radical scavenging capacity of the extracts was determined using modified 2,2-diphenyl-1-picrylhydrazyl (DPPH) method [25]. Briefly, freshly prepared DPPH solution $(0.4 \%)$ in $95 \%$ methanol was taken in test tubes, and sample extract appropriately diluted in the range of 5-20 $\mu$ l was added to every test tube so that the final volume was $3 \mathrm{~mL}$ and after $10 \mathrm{~min}$, the absorbance was read at $517 \mathrm{~nm}$ using a colorimeter (CL-157, ELICO Ltd., Hyderabad, India). Ascorbic acid (Hi-Media laboratory, Mumbai, India) was used as a reference standard. The stock solution was made to $0.1 \mathrm{M}, 0.01 \mathrm{M}$, and $0.001 \mathrm{M}$ using distilled water. $95 \%$ methanol was used as blank. Experiments were performed in triplicates and represented as percentage of mean inhibition \pm standard error. Percentage scavenging of the DPPH free radical was measured, using following formula:

$\%$ Scavenging of the DPPH free radical=(Absorbance of the controlAbsorbance of the test sample)/Absorbance of the control) $\times 100$

\section{Cell culture}

PA-1 (ovarian teratocarcinoma metastatic) and Vero cell line (monkey kidney cells) were obtained from National Center for Cell Sciences, Pune, India. Head and neck squamous cell carcinoma cell lines and Cal-27 were obtained from Institute of Bioinformatics, Bangalore, and cisplatinresistant subline (Cal-27 CisR) was developed and characterized in the laboratory (Mazumdar Shaw Centre for Translational research, MSCTR), Bangalore, was used in this study [22]. The monolayer cultures grown in Dulbecco's Modified Eagle Medium (DMEM) (Thermo Fisher Scientific, Massachusetts, U.S.A) supplemented with $10 \%$ fetal bovine serum (FBS) (Thermo Fisher Scientific). The resistant cell lines were cultured in the presence of the drug (Cisplatin; IC 6.25 each).
Mice, dysplastic cell line, DysMSCTR16 developed in the MSCTR, Bangalore, were also maintained in monolayer cultures in DMEM:F12 (Thermo Fisher Scientific, Massachusetts, U.S.A) supplemented with $20 \%$ FBS and growth factors (data unpublished, Indian provisional Patent: TEMP/E-1/20383/2017 - CHE).

\section{Cell viability assay}

Viability of treated and untreated cells was evaluated using 3-(4,5-dimethylthiazol-2-yl)-2,5-diphenyltetrazolium bromide (MTT) assay as per standard protocols. Briefly, $1 \times 10^{4}$ cells/well were plated for $18 \mathrm{~h}$ in 96-well plate before the treatment with different concentrations of amla, ginger extract ( $5 \mu \mathrm{l}$ and $25 \mu \mathrm{l})$, and ascorbic acids $(0.25 \mathrm{mM}$ and $2 \mathrm{mM}$ ) for $24 \mathrm{~h}$ and $48 \mathrm{~h}$ in $100 \mu \mathrm{l}$ media/well. Cells were then incubated with $20 \mu \mathrm{l}$ of MTT ( $5 \mathrm{mg} / \mathrm{mL}$ ) (\#M5655, Sigma, USA) for $4 \mathrm{~h} \mathrm{(37C)} \mathrm{and}$ the formazan crystals formed dissolved in DMSO $(100 \mu \mathrm{l})$. The plate was read at $570 \mathrm{~nm}$ (test) and $690 \mathrm{~nm}$ (reference) in Tecan Infinite F200 Pro (Bio-Rad Laboratories, Inc., USA). The percentage viability was calculated using the formula (Mean OD of the test/Mean OD of the control)*100. All the experiments were carried out in triplicates.

\section{Spheroid formation assay}

To assess the spheroid forming ability of cells, Cal-27 and Cal-27 CisR cell lines were plated along with amla, ginger, and ascorbic acid. Briefly, a required number of single cells (1000 cells/well) were resuspended in serum free, DMEM: F12 medium supplemented with 1\% N2 supplement, $20 \mathrm{ng} / \mathrm{mL}$ human basic fibroblast growth factor, $20 \mathrm{ng} / \mathrm{mL}$ human epidermal growth factor, $5 \mathrm{mg} / \mathrm{mL}$ of insulin, and cultured in 24-well ultra-low attachment plates for 10-12 days. The medium was supplemented with the growth factors every 2 days and the number of spheroids was counted after 12 days. All the experiments were done in triplicates and average number was plotted.

\section{Colony Formation Assay}

Colony formation capacities of the DysMSCTR16, Cal-27, and Cal-27 CisR cell lines were evaluated by plating 500 cells in a 24 -well cell culture plate and cultured for 14 days in the presence of amla, ginger, and ascorbic acid. Colonies were fixed and stained with Giemsa stain (Hi-Media Pvt., Ltd., Mumbai, India). 50 cells per clone were counted manually. The colonyforming capacity of each cell line was compared with untreated control cells, and results were concluded from triplicate experiments.

\section{Statistical analysis}

Statistical significance for MTT assay, colony formation, and spheroid formation assays was determined among different cell lines in comparison to the untreated cell lines. The unpaired t-test was used for calculating significance in all the experiments (GraphPad Prism Software 7.0).

\section{RESULTS}

TAC

TAC determines the efficacy of an antioxidant to donate its electrons. TAC was expressed in terms of ascorbic acid equivalents. The TAC of $5 \mu \mathrm{l}$ of amla and ginger was found be equivalent to $202 \mu \mathrm{M}$ and $47 \mu \mathrm{M}$ ascorbic acid, respectively, as given in Table 1.

\section{DPPH radical scavenging activity}

DPPH is a free radical donor, which has been used widely in studying the free radical scavenging capability of various compounds. The method is based on the reduction in absorbance at $517 \mathrm{~nm}$ in the presence

Table 1: Total antioxidant capacity ( $\mu \mathrm{M}$ ascorbic acid equivalents) of amla and ginger

\begin{tabular}{lll}
\hline Sample & $\begin{array}{l}\text { Average absorbance } \\
\text { at } \mathbf{6 9 5} \mathbf{~ n m ~}\end{array}$ & $\begin{array}{l}\text { Ascorbic acid } \\
\text { equivalent }(\boldsymbol{\mu M})\end{array}$ \\
\hline Amla & $0.202 \pm 0.01$ & 202 \\
Ginger & $0.047 \pm 0.02$ & 47 \\
\hline Absorbance=Avg. & Mean $(\mathrm{n}=3) \pm$ SE. SE: Standard error
\end{tabular}


of proton-donating substance, accompanied by a sharp color change from purple to yellow. The crude extracts of amla and ginger showed a significant decrease in both absorbance and the color change.

Every $5 \mu \mathrm{l}$ of aqueous extract of amla and ginger showed scavenging activity of $16 \%$ and $21 \%$, respectively (Fig. 1a). Aqueous extract of amla showed same scavenging activity at both its native $(\mathrm{pH} 3)$ and adjusted physiological $\mathrm{pH}$ 7. These observations showed that ginger and amla both are good antioxidants. Although ginger showed that the higher radical scavenging capacity and amla have higher TAC.

Effect of antioxidants on normal, dysplastic, cancer, and resistant cell line

Normal kidney cell line, Vero cells showed a significant decrease in percentage viability $(\mathrm{p}<0.0001)$ by end of $48 \mathrm{~h}$ in both low dose $0.25 \mathrm{mM}$ ascorbic acid (55\% \pm 0.023$)$ and high dose $2 \mathrm{mM}(1 \% \pm 0.3)$; amla $5 \mu \mathrm{l}$ $(7 \% \pm 0.47)$ and $25 \mu \mathrm{l}(0 \% \pm 0.001)$; and ginger $5 \mu \mathrm{l}(67 \% \pm 0.094)$ and $25 \mu \mathrm{l}$ ginger $(15 \% \pm 0.31)$ as compared to control untreated Vero cells (100\%) (Fig. 1b). These results show that the cells are susceptible to the presence of antioxidants in the culture media for longer period.

Dysplastic cell line, DysMSCTR16, showed no significant effect on cell viability at $48 \mathrm{~h}$ of treatment with both low and high doses of ascorbic acid as well as extracts of amla and ginger as compared to control untreated DysMSCTR16 cells (100\%) (Fig. 1c).

In teratoma cell line PA-1, a $48 \mathrm{~h}$ of treatment with ascorbic acid and higher dose of amla were significantly effective in decreasing the cell viability, ascorbic acid $0.25 \mathrm{mM}(6.25 \% \pm 0.034 ; \mathrm{p}=0.0001)$ and $2 \mathrm{mM}$ ascorbic acid ( $0 \% \pm .01 ; \mathrm{p}=0.0001)$; and $25 \mu \mathrm{l}$ amla $(0 \% \pm 0.62 ; \mathrm{p}=0.0001)$. Low dose of amla and ginger extract failed to inhibit the proliferation in PA-1 cell line as compared to untreated control PA-1 cells (Fig. 1d).

In oral squamous cell carcinoma cell line Cal-27, all the antioxidants ascorbic acid, amla, and ginger extract were significantly effective in controlling the cell proliferation at $48 \mathrm{~h}$. Cell viability was significantly affected at $0.25 \mathrm{mM}$ ascorbic acid $(85 \% \pm 0.28 ; \mathrm{p}=0.003)$ and $2 \mathrm{mM}$ ascorbic acid $(86 \% \pm 0.42 ; \mathrm{p}=0.02) ; 5 \mu \mathrm{l}$ amla $(64.7 \% \pm 0.02 ; \mathrm{p}=0.002)$ and $25 \mu \mathrm{l}$ amla $(93.5 \% \pm 0.02 ; \mathrm{p}=0.004)$; and $5 \mu \mathrm{l}$ ginger $(84.2 \% \pm 0.02$; $\mathrm{p}=0.04)$ and $25 \mu \mathrm{l}$ ginger $(91 \% \pm 0.02 ; \mathrm{p}=0.04)$ as compared to the untreated control Cal-27 (Fig. 1e).

The percent cell viability of cisplatin-resistant cell line, Cal-27 CisR decreased after $48 \mathrm{~h}$ of treatment with high dosage of antioxidants; $2 \mathrm{mM}$ ascorbic acid $(30 \% \pm 0.18 ; \mathrm{p}=0.04)$; amla $25 \mu \mathrm{l}(68 \% \pm 0.29$; $\mathrm{p}=0.03)$; and $25 \mu$ l ginger $(52 \% \pm 0.91 \mathrm{p}=0.04)$ (Fig. 1f).
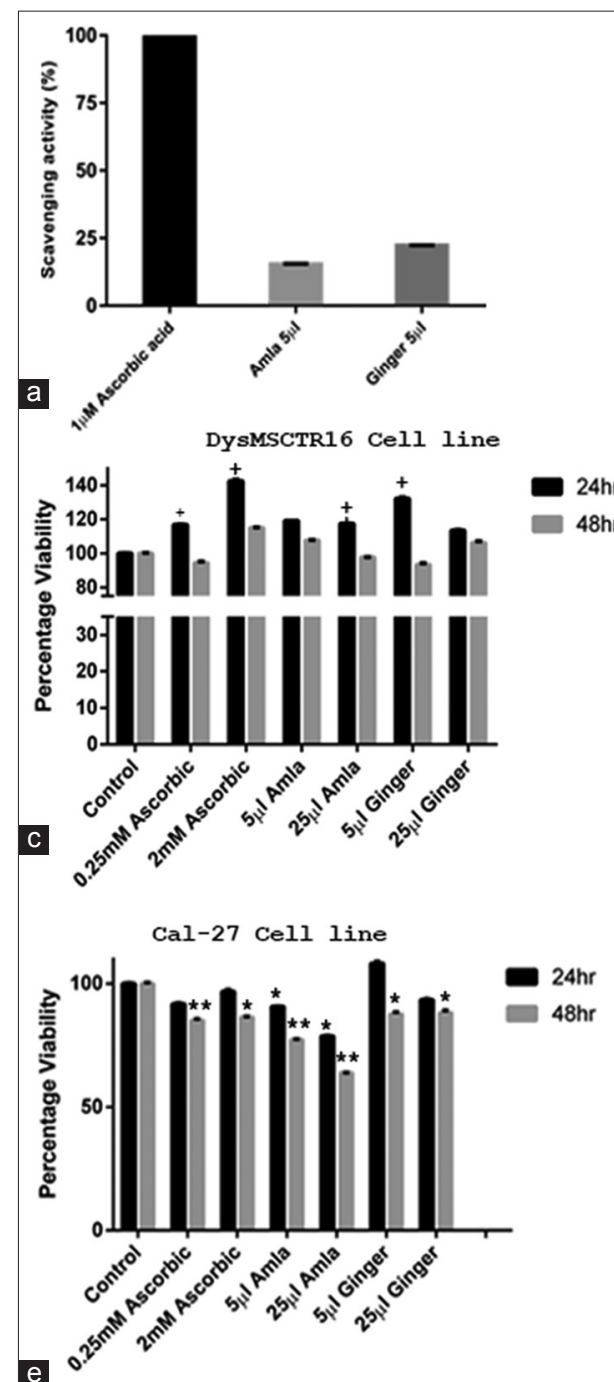

b

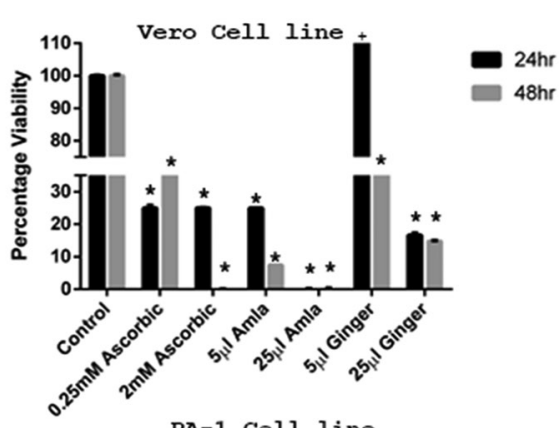

PA-1 Cell line
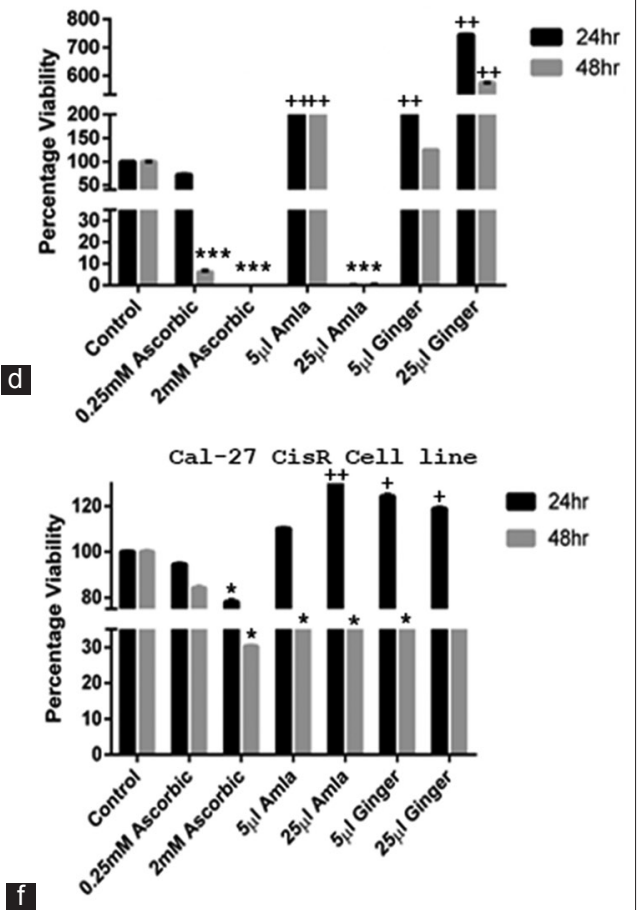

Fig. 1: Represents the percentage scavenging activity of $5 \mu \mathrm{l}$ of amla and ginger extract as compared to the $1 \mu \mathrm{M}$ ascorbic acid (a). Proliferation assay confirms the effect of amla, ascorbic acid, and ginger on Vero cells (b), DysMSCTR16 cells (c), PA-1 cells (d), Cal-27 cells (e), and Cal-27 CisR (f) cell line at 24 and $48 \mathrm{~h}$ treatment. All of the experiments were performed in triplicates. Results show the mean SE of three independent assays. Statistical significance is also represented $\left(* \mathrm{p}<0.05,{ }^{* *} \mathrm{p}<0.005,{ }^{* * *} \mathrm{p}<0.0005\right) .\left({ }^{*}\right)$ represents the inhibitory significant data; $(+)$ represents the anti-inhibitory significant data 


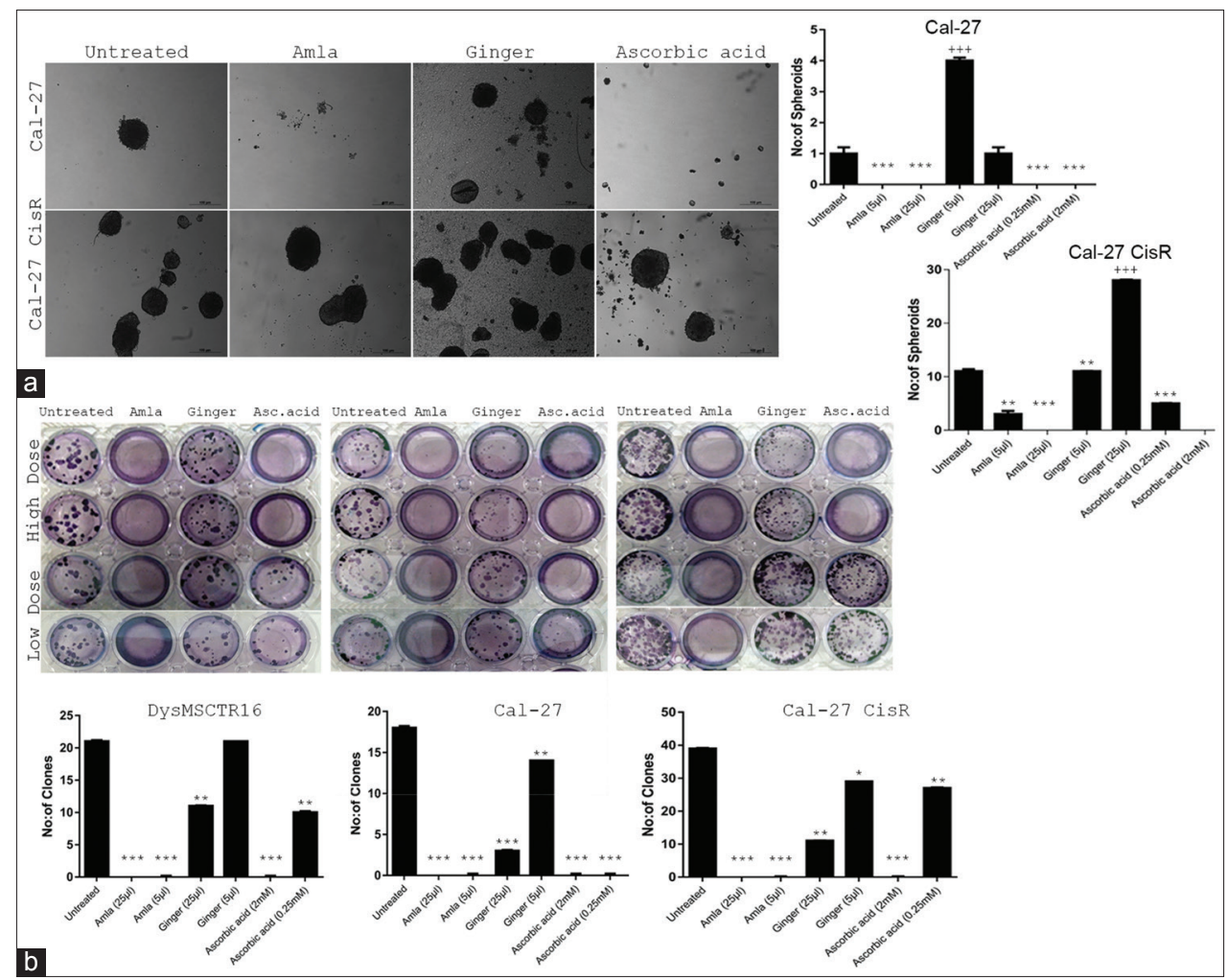

Fig. 2: Functional assay showing the inhibitory action of amla and ascorbic acid on spheroid formation on Cal-27 and Cal-27 CisR cells (a) and anchorage-dependent self-renewal capacity (colony formation capacity) in DysMSCTR12, Cal-27, and Cal-27 CisR cell lines. Ginger extract shows no significant inhibitory effect on cell lines. All of the experiments were performed in triplicates. Results show the mean SE of three independent assays. Statistical significance is also represented $\left({ }^{*} p<0.05,{ }^{* *} p<0.005, * * * p<0.0005\right) .\left({ }^{*}\right)$ represents the inhibitory significance data; $(+)$ represents the anti-inhibitory significant data

Results of the cell viability study suggest that at the chosen dosage of ascorbic acid $(0.25 \mathrm{mM}$ and $2 \mathrm{mM})$, amla extract $(5 \mu \mathrm{l}$ and $25 \mu \mathrm{l})$, and ginger extract $(5 \mu \mathrm{l}$ and $25 \mu \mathrm{l})$ were significantly effective in controlling cell proliferation of normal kidney cells (non-cancerous cells). Cell proliferation of dysplastic cells DysMSCTR16 was not affected any of the antioxidants used in this study. Cell viability of PA-1 cells was significantly reduced by ascorbic acid and high dose of amla extract only. Proliferation of squamous cell carcinoma cells (Cal-27) was significantly affected by all the studied antioxidants. Proliferation of cisplatin-resistant cells (Cal-27 CisR cell line) was significantly affected only at higher concentrations of the studied antioxidants.

Effect of antioxidants on anchorage-independent self-renewal capacity (spheroid formation) of cancer cells

Spheroid formation capabilities of Cal-27 and Cal-27 CisR cells were analyzed in the presence of crude extracts of amla, ginger, and ascorbic acid. Cal-27 cells showed a significant inhibition in the spheroid formation capacity in the presence of both low and high dose of amla and ascorbic acid ( $n=0, p<0.0001)$, whereas, lower dose of ginger $(5 \mu \mathrm{l})$ showed a significant increase in number of spheroids formed $(n=4, p<0.0001)$ as compared to the untreated control Cal-27 $(n=1)$.

In Cal-27 CisR, $25 \mu \mathrm{l}$ amla and $2 \mathrm{mM}$ ascorbic acid were effective in inhibiting the spheroid formation capacity $(n=0, p<0.0001)$. Lower dose $(5 \mu \mathrm{l})$ amla $(\mathrm{n}=3)$ and $0.25 \mathrm{mM}$ ascorbic acid $(\mathrm{n}=5) \mathrm{p}<0.0001)$ could significantly reduce the spheroid formation capacity as compared to the untreated Cal-27 CisR cells ( $n=11)$. On the other hand, ginger extract showed an increase in spheroid formation capacity of Cal-27 CisR cell line $(\mathrm{n}=28, \mathrm{p}<0.0001)$ (Fig. 2a).
Effect of antioxidants on anchorage-dependent self-renewal capacity (colony formation) of cancer cells

DysMSCTR16, Cal-27, and Cal-27 CisR cells were used to evaluate the effect of antioxidants (ascorbic acid and crude extracts of amla and ginger) on colony formation capacity of cancer cells.

In DysMSCTR16 and Cal-27 cells, both amla and ascorbic acid showed a complete inhibition of the colony formation capacity $(n=0, p<0.0001)$, and only high dose $(25 \mu \mathrm{l})$ of ginger extract reduced the colony formation capacity to $50 \%$ DysMSCTR16 ( $n=11, \mathrm{p}<0.0001$ ), Cal-27 $(\mathrm{n}=3, \mathrm{p}<0.0001)$ as compared to the untreated control DysMSCTR16 $(\mathrm{n}=21)$ and Cal-27 $(\mathrm{n}=11)$. Low-dose ginger $(5 \mu \mathrm{l})$ did not show any inhibitory effect in DysMSCTR16 (n=21) (Fig. 2b).

In Cal-27 CisR cells, amla extract and $2 \mathrm{mM}$ ascorbic acid showed full inhibition of colony formation $(n=0, p<0.0001)$ and as compared to untreated control Cal-27 CisR ( $\mathrm{n}=39)$. Low dose of $0.25 \mathrm{mM}$ ascorbic acid showed low significant reduction in clone formation $(n=27$, $\mathrm{p}<0.003$ ). Ginger extract showed least significant reduction in clone formation capacity in both low dose $5 \mu$ ginger $(n=29, p<0.05)$ and 25 $\mu \mathrm{l}$ ginger $(\mathrm{n}=11, \mathrm{p}<0.004)$ as compared to the untreated control Cal-27 CisR (n=39) (Fig. 2b).

Amla and ascorbic acid showed a significant effect in controlling the self-renewal capacity of cells in various lineages of cancer cell.

\section{DISCUSSION}

Accumulating evidence suggests that many dietary factors like antioxidants (polyphenols) are used alone or in combination with traditional/conventional chemotherapy to prevent or treat cancer [26-35]. Crude and processed plant extracts are studied 
extensively to evaluate its role in treatment as chemopreventive drug or to use in combination that can synergistically improve the outcome of current chemotherapy and lower the toxicity [36-38]. European Prospective Investigation into Cancer and Nutrition is one such agency that studies the relationship between diet and cancer [29,39-41].

Many chemopreventive therapies utilize polyphenolic components such as curcumin, ginger, Vitamin $\mathrm{C}$, amla, and green tea extracts as cancer therapy [42-46]. The primary mechanism of many chemotherapy and radiotherapy system is generation of reactive oxygen species in the cancer cells to induce apoptosis. Free radicals produced during the therapy causes serious side-effect and toxicity in the patients. For more than two decades, discussion continues on whether antioxidants should be used along with chemotherapy and radiation. Many oncologists now advise patients to discontinue antioxidant type ingredients which may also include fruits and vegetables used in higher quantities than recommended in diet. Apart from the common usage, new studies also highlight on crossover between antioxidant to pro-oxidant property of polyphenols based on the concentration, solubility, formulation, dosage, and combination with metal ions during the intake [42,47-49].

In our study, we highlighted on the use of aqueous extracts of ascorbic acid, amla, and ginger to evaluate its effect on different lineages of cancers. We observed that a low dosage of ascorbic acid $(0.25 \mathrm{mM})$ and low-dose aqueous extract of fresh amla $(0.25 \mathrm{~g} / \mathrm{mL})$ were effective in controlling the cell proliferation of ovarian tetratomic (PA-1), oral cancer (Cal-27); whereas the cisplatin-resistant (Cal-27 CisR) cell line was effected only at high dose $(2 \mathrm{mM}$ ascorbic acid and $25 \mu \mathrm{l}$ of amla extract). Is the inefficacy due to increasing percentage of CSC population in Cal-27, PA-1, and Cal-27 CisR cells? [22,50]. Dysplasia cells (DysMSCTR16) were not affected by ascorbic acid or the amla and ginger extracts, in regard to cell proliferation. This may be due to slow growth of dysplasia cells as compared to cancer cells or may be even higher concentration of extracts required to trigger cell death. It was also observed that aqueous extract of fresh ginger was not as effective as amla extract and ascorbic acid, in controlling the proliferation of cells even after $48 \mathrm{~h}$ of treatment, as observed in dysplastic, teratoma, and cisplatin-resistant cells. To further assess, we looked into the inhibitory effect of extracts on the self-renewal capacity of cells using spheroid and colony formation capacity. We observed that longer exposure of amla and ascorbic acid was able to inhibit both spheroid and colony formation among various lineages of cancer cells including dysplasia cell lines. Ginger extract, on the other hand, showed to increase or insignificant effect in controlling the anchorage-independent self-renewal capacity of spheroid formation capacity of oral squamous cell line and cisplatinresistant cell line. However, high dose of ginger was able to inhibit anchorage-dependent growth (colony formation capacity) of cancer cells. Although the total antioxidant and scavenging capacity were in the same range between amla and ginger, yet the effects were different in functional aspects. Suggesting that, the observed effects could also be due to the nature, structure and origin of the antioxidants, and only on the antioxidant potential. Inhibition of clone formation in dysplasia cells also indicated toward a longer incubation of extracts to be effective in controlling the cell viability and growth of dysplasia cell line.

Polyphenols are extracted in organic solvents for high yield as compared to the aqueous extraction. Previous studies highlight on anticancer property of amla and ginger extracts and are used as chemopreventive and therapeutic drug in tradition medicines [3,51-55]. Our study focused on evaluating the direct effect of aqueous extract of ginger and amla, in its natural dietary form. Ginger is traditionally used in tea and as "trikatu" as a therapeutic decoction to improve the immunity, metal detoxification, digestion, and fight against the cold inflammation in Indian continent [56-60]. High doses of antioxidants have been shown to inhibit the growth of different rodent and human cancer cells in vivo and in vitro [61-65]. Dose-dependent effect of antioxidant (prooxidant and antioxidant theory) of the known "antioxidants" on normal and cancer cell is still not well established [66]. Nutrients such as carotenoids, tocopherol, or ascorbate derivatives show an antioxidant or pro-oxidant characteristic depending on the redox potential of the individual molecule and the inorganic chemistry of the cell $[65,67,68]$. We used low and high doses of extracts that relied on scavenging and TOC activity (Fig. 1). This could be due to nature and structure of the phytochemicals present in the ginger extract as compared to the amla extract. Hence, this suggests that the chemical nature and structure of the antioxidant also contributes toward the bioactivity, rather than the antioxidant property as a sole parameter. This is due to aqueous formulation or grated form of fresh ginger is not yet clear. Traditional medicine describes the use of dried ginger or whole ginger crushed decoction form for therapy. Antioxidant activity is highly correlated to total phenols concentration in the extract. The extracting solvent significantly altered the antioxidant property of the extracts [69]. We still have to evaluate, whether the lack of anticancer property of ginger is due to its extraction protocol and loss of anticancer components. There is also possibility of transformation of component during the extraction. Dried ginger and fresh ginger extracts may be maturing components that showed anticancer property. Question now raised is to use ginger aqueous extract in diet during and postchemotherapy or not. There is possibility that during extraction process of grating and boiling, ginger juice may have lost its anticancer components. However, amla seems to be better potential candidate for anticancer activity.

\section{ACKNOWLEDGMENTS}

The authors would like to acknowledge Dr. Moni Abraham Kuriakose (MD, FRCS), Professor and Director Department of Surgical Oncology, Head and Neck Oncology, Narayana Health, Bangalore, for his eminent support and guidance enabling a fruitful completion of the study.

\section{AUTHOR'S CONTRIBUTIONS}

1. Safeena Kulsum: Design of the work; the acquisition, analysis, and interpretation of data, drafting/revising the work.

2. Amritha Suresh: Guidance in cancer stem cell-based assays, draft correction, and final approval for publication.

3. Alka Mehta: Study design, guidance in antioxidant assays, analysis, and interpretation of data, drafting/revising the work draft preparation, final approval for publication.

\section{CONFLICTS OF INTEREST}

The authors declare that they have no conflicts of interest.

\section{REFERENCES}

1. Bhatt ID, Rawat S, Badhani A, Rawal RS. Nutraceutical potential of selected wild edible fruits of the indian himalayan region. Food Chem 2017;215:84-91.

2. Wang CC, Yuan JR, Wang CF, Yang N, Chen J, Liu D, et al. Antiinflammatory effects of phyllanthus emblica 1 on benzopyrene-induced precancerous lung lesion by regulating the il-1beta/mir-101/lin $28 \mathrm{~b}$ signaling pathway. Integr Cancer Ther 2017;16:505-15.

3. De A, Powers B, De A, Zhou J, Sharma S, Van Veldhuizen P, et al. Emblica officinalis extract downregulates pro-angiogenic molecules via upregulation of cellular and exosomal mir-375 in human ovarian cancer cells. Oncotarget 2016;7:31484-500.

4. Susanti SK, Santoso IS, Murwanti R, Suzery M, Oku H.Comparison on the cancer specific cytotoxicity of three gingers (Zingiber officinale rosc) leaves varieties from indonesia. Int $\mathrm{J}$ Pharm Phytochem Res 2017;9:129-34.

5. Kalantari K, Moniri M, Boroumand Moghaddam A, Abdul Rahim R, Bin Ariff A, Izadiyan Z, et al. A review of the biomedical applications of zerumbone and the techniques for its extraction from ginger rhizomes. Molecules 2017;22:pii: E1645.

6. Marx W, Ried K, McCarthy AL, Vitetta L, Sali A, McKavanagh D, et al. Ginger-mechanism of action in chemotherapy-induced nausea and vomiting: A review. Crit Rev Food Sci Nutr 2017;57:141-6.

7. Pournaderi PS, Yaghmaei P, Khodaei H, Noormohammadi Z, Hejazi SH. The effects of 6-gingerol on reproductive improvement, liver functioning and cyclooxygenase-2 gene expression in estradiol valerate - induced polycystic ovary syndrome in wistar rats. Biochem Biophys Res Commun 2017;484:461-6. 
8. Zheng J, Zhou Y, Li Y, Xu DP, Li S, Li HB, et al. Spices for prevention and treatment of cancers. Nutrients 2016;8:pii: E495.

9. Roomi MW, Kalinovsky T, Rath M, Niedzwiecki A. A specific mixture of nutrients suppresses ovarian cancer A-2780 tumor incidence, growth, and metastasis to lungs. Nutrients 2017;9: pii: E303.

10. Fredotovic Z, Sprung M, Soldo B, Ljubenkov I, Budic-Leto I, Bilusic T, et al. Chemical composition and biological activity of allium cepa 1 . And allium x cornutum (clementi ex visiani 1842) methanolic extracts. Molecules 2017;22:pii: E448.

11. Egnell M, Fassier P, Lecuyer L, Gonzalez R, Zelek L, Vasson MP, et al. Antioxidant intake from diet and supplements and risk of digestive cancers in middle-aged adults: Results from the prospective nutrinetsante cohort. Br J Nutr 2017;118:541-49.

12. Wilms D, Andra J.Comparison of patient-derived high and low phosphatidylserine-exposing colorectal carcinoma cells in their interaction with anti-cancer peptides. J Pept Sci 2017;23:56-67.

13. Leong SY, Burritt DJ, Hocquel A, Penberthy A, Oey I. The relationship between the anthocyanin and vitamin c contents of red-fleshed sweet cherries and the ability of fruit digests to reduce hydrogen peroxideinduced oxidative stress in caco-2 cells. Food Chem 2017;227:404-12.

14. Ashita S, Mandeep K, Jatinder Kaur K, Avinash Kaur N. Polyphenols in food: Cancer prevention and apoptosis induction. Current Medicinal Chemistry 2017;24:1-18

15. Shivakumar A, Yogendra Kumar MS. Critical review on the analytical mechanistic steps in the evaluation of antioxidant activity. Crit Rev Anal Chem 2018:48:214-36.

16. Suarez-Arroyo IJ, Loperena-Alvarez Y, Rosario-Acevedo R, MartinezMontemayor MM. Ganoderma spp.: A promising adjuvant treatment for breast cancer. Medicines (Basel) 2017;4:1-29.

17. Li T, Fu X, Tse AK, Guo H, Lee KW, Liu B, et al. Inhibiting stat3 signaling is involved in the anti-melanoma effects of a herbal formula comprising sophorae flos and lonicerae japonicae flos. Sci Rep 2017;7:3097.

18. Roter DL, Yost KJ, O'Byrne T, Branda M, Leppin A, Kimball B, et al. Communication predictors and consequences of complementary and alternative medicine (cam) discussions in oncology visits. Patient Educ Couns 2016;99:1519-25.

19. Ohkoshi E, Umemura N. Induced overexpression of cd44 associated with resistance to apoptosis on DNA damage response in human head and neck squamous cell carcinoma cells. Int J Oncol 2017;50:387-95.

20. Naik PP, Das DN, Panda PK, Mukhopadhyay S, Sinha N, Praharaj PP, et al. Implications of cancer stem cells in developing therapeutic resistance in oral cancer. Oral Oncol 2016;62:122-35.

21. Simple M, Suresh A, Das D, Kuriakose MA. Cancer stem cells and field cancerization of oral squamous cell carcinoma. Oral Oncol 2015;51:643-51.

22. Kulsum S, Sudheendra HV, Pandian R, Ravindra DR, Siddappa G, R N, et al. Cancer stem cell mediated acquired chemoresistance in head and neck cancer can be abrogated by aldehyde dehydrogenase $1 \mathrm{~A} 1$ inhibition. Mol Carcinog 2017:56:694-711.

23. Siddappa G, Kulsum S, Ravindra DR, Kumar VV, Raju N, Raghavan N, et al. Curcumin and metformin-mediated chemoprevention of oral cancer is associated with inhibition of cancer stem cells. Mol Carcinog 2017;56:2446-60.

24. Prieto P, Pineda M, Aguilar M. Spectrophotometric quantitation of antioxidant capacity through the formation of a phosphomolybdenum complex: Specific application to the determination of vitamin E. Anal Biochem 1999;269:337-41.

25. Mensor LL, Menezes FS, Leitão GG, Reis AS, dos Santos TC, Coube CS, et al. Screening of brazilian plant extracts for antioxidant activity by the use of DPPH free radical method. Phytother Res 2001;15:127-30

26. Abubakar IB, Lim KH, Kam TS, Loh HS. Enhancement of apoptotic activities on brain cancer cells via the combination of $\gamma$-tocotrienol and jerantinine A. Phytomedicine 2017;30:74-84.

27. Adaramoye O, Erguen B, Nitzsche B, Höpfner M, Jung K, Rabien A, et al. Punicalagin, a polyphenol from pomegranate fruit, induces growth inhibition and apoptosis in human PC-3 and LNCaP cells. Chem Biol Interact 2017:274:100-6.

28. Afrin S, Forbes-Hernandez TY, Gasparrini M, Bompadre S, Quiles JL, Sanna G, et al. Strawberry-tree honey induces growth inhibition of human colon cancer cells and increases ROS generation: A Comparison with manuka honey. Int J Mol Sci 2017;18:pii: E613.

29. Vitale M, Vaccaro O, Masulli M, Bonora E, Del Prato S, Giorda CB, et al. Polyphenol intake and cardiovascular risk factors in a population with Type 2 diabetes: The TOSCA.IT study. Clin Nutr 2017;36:1686-92.

30. Nunez-Sanchez MA, Gonzalez-Sarrias A, Garcia-Villalba R,
Monedero-Saiz T, Garcia-Talavera NV, Gomez-Sanchez MB, et al. Gene expression changes in colon tissues from colorectal cancer patients following the intake of an ellagitannin-containing pomegranate extract: A randomized clinical trial. J Nutr Biochem 2017;42:126-33.

31. Venkata KC, Anand S, Debasis B, Anupam B. A small plant with big benefits: Fenugreek (trigonella foenum-graecum linn.) for disease prevention and health promotion. Molecular Nutrition \& Food Research 2017;61:1600950.

32. Colomer R, Sarrats A, Lupu R, Puig T. Natural polyphenols and their synthetic analogs as emerging anticancer agents. Curr Drug Targets 2017; $18: 147-59$.

33. Tafazoli A. Coenzyme q10 in breast cancer care. Future Oncol 2017;13:1035-41.

34. Nikseresht M, Kamali AM, Rahimi HR, Delaviz H, Toori MA, Kashani IR, et al. The hydroalcoholic extract of matricaria chamomilla suppresses migration and invasion of human breast cancer mda-mb-468 and mef-7 cell lines. Pharmacognosy Res 2017;9:87-95

35. Ashraf K, Sultan S, Shah SA. Phychemistry, phytochemical, pharmacological and molecular study of zingiber officinale roscoe: A review. Int J Pharm Pharm Sci 2017:9:8-16

36. Pounis G, Di Castelnuovo A, Bonaccio M, Costanzo S, Persichillo M, Krogh V, et al. Flavonoid and lignan intake in a mediterranean population: Proposal for a holistic approach in polyphenol dietary analysis, the moli-sani study. Eur J Clin Nutr 2016;70:338-45.

37. Bastide N, Dartois L, Dyevre V, Dossus L, Fagherazzi G, Serafini M, et al. Dietary antioxidant capacity and all-cause and cause-specific mortality in the e3n/epic cohort study. Eur J Nutr 2017;56:1233-43.

38. Bakker MF, Peeters PH, Klaasen VM, Bueno-de-Mesquita HB, Jansen EH, Ros MM, et al. Plasma carotenoids, vitamin c, tocopherols, and retinol and the risk of breast cancer in the european prospective investigation into cancer and nutrition cohort. Am J Clin Nutr 2016;103:454-64.

39. Noh H, Freisling H, Assi N, Zamora-Ros R, Achaintre D, Affret A, et al. Identification of urinary polyphenol metabolite patterns associated with polyphenol-rich food intake in adults from four European countries. Nutrients 2017;9:pii: E796.

40. Vece MM, Agnoli C, Grioni S, Sieri S, Pala V, Pellegrini N, et al. Dietary total antioxidant capacity and colorectal cancer in the italian epic cohort. PLoS One 2015;10:e142995.

41. Jeurnink SM, Ros MM, Leenders M, van Duijnhoven FJ, Siersema PD, Jansen EH, et al. Plasma carotenoids, vitamin c, retinol and tocopherols levels and pancreatic cancer risk within the European prospective investigation into cancer and nutrition: A nested case-control study: Plasma micronutrients and pancreatic cancer risk. Int $\mathrm{J}$ Cancer 2015; 136:E665-76

42. Dai F, Liu GY, Li Y, Yan WJ, Wang Q, Yang J, et al. Insights into the importance for designing curcumin-inspired anticancer agents by a prooxidant strategy: The case of diarylpentanoids. Free Radic Biol Med 2015;85:127-37.

43. Lea MA. Flavonol regulation in tumor cells. J Cell Biochem 2015;116:1190-4.

44. Tao L, Park JY, Lambert JD. Differential prooxidative effects of the green tea polyphenol, (-)-epigallocatechin-3-gallate, in normal and oral cancer cells are related to differences in sirtuin 3 signaling. Mol Nutr Food Res 2015;59:203-11

45. Lee WJ. The prospects of vitamin $\mathrm{c}$ in cancer therapy. Immune Netw 2009;9:147-52.

46. Ramaswamy JS, Reddy CU. Comparative study of in silico and in vitro anticancer activity of traditional indian medicinal plants-a reverse pharmacological approach. Int J Curr Pharm Res 2017;9:42-6.

47. Alamdari DH, Aghasizadeh-Sharbaf M, Mohadjerani M, Ferns GA, Avan A. Prooxidant-antioxidant balance and antioxidant properties of thuja orientalis 1: A potential therapeutic approach for diabetes mellitus. Curr Mol Pharmacol 2018:11:109-12.

48. Andrade Volkart P, Benedetti Gassen R, Mühlen Nogueira B, Nery Porto B, Eduardo Vargas J, Arigony Souto A, et al. Antitumor activity of resveratrol is independent of cu(II) complex formation in MCF-7 cell line. Bioorg Med Chem Lett 2017;27:3238-42.

49. Fernandes AP, Gandin V. Selenium compounds as therapeutic agents in cancer. Biochim Biophys Acta 2015;1850:1642-60.

50. Hu K, Yin F, Yu M, Sun C, Li J, Liang Y, et al. In-tether chiral center induced helical peptide modulators target $\mathrm{p} 53-\mathrm{mdm} 2 / \mathrm{mdmx}$ and inhibit tumor growth in stem-like cancer cell. Theranostics 2017;7:4566-76.

51. Eren D, Betul YM. Revealing the effect of 6-gingerol, 6-shogaol and curcumin on mpges-1, gsk-3beta and beta-catenin pathway in a549 cell line. Chem Biol Interact 2016;258:257-65.

52. Kaur IP, Deol PK, Kondepudi KK, Bishnoi M. Anticancer potential 
of ginger: Mechanistic and pharmaceutical aspects. Curr Pharm Des 2016;22:4160-72.

53. Kapoor V, Aggarwal S, Das SN. 6-gingerol mediates its anti tumor activities in human oral and cervical cancer cell lines through apoptosis and cell cycle arrest. Phytother Res 2016;30:588-95.

54. Chavare A, Chowdari P, Ghosh S, Pawar P, Patkar M, Dakave S, et al. Safety and bioactivity studies of jasad bhasma and its in-process intermediate in swiss mice. J Ethnopharmacol 2017;197:73-86.

55. Saraphanchotiwitthaya PS. Immunomodulatory effect of different proportions of the herbal mixture in triphala on human t lymphocytes (molt-4). Int J Pharm Pharm Sci 2015;7:282-8.

56. Gopalsamy B, Farouk AA, Mohamad TA, Sulaiman MR, Perimal EK. Antiallodynic and antihyperalgesic activities of zerumbone via the suppression of il-1beta, il-6, and tnf-alpha in a mouse model of neuropathic pain. J Pain Res 2017;10:2605-19.

57. Mekuria AB, Erku DA, Gebresillassie BM, Birru EM, Tizazu B, Ahmedin A. Prevalence and associated factors of herbal medicine use among pregnant women on antenatal care follow-up at university of gondar referral and teaching hospital, ethiopia: A cross-sectional study. BMC Complement Altern Med 2017;17:86

58. Kulkarni RA, Deshpande AR. Anti-inflammatory and antioxidant effect of ginger in tuberculosis. J Complement Integr Med 2016;13:201-6.

59. Johri RK, Zutshi U. An ayurvedic formulation 'trikatu' and its constituents. J Ethnopharmacol 1992;37:85-91.

60. Ashraf SS, Shah SA. Phychemistry, phytochemical, pharmacological and molecular study of Zingiber officinale roscoe: A review. Int J Pharm Pharm Sci 2017;9:8-16.

61. Krishnamoorthy D, Sankaran M. Modulatory effect of pleurotus ostreatus on oxidant/antioxidant status in 7, 12-dimethylbenz (a) anthracene induced mammary carcinoma in experimental rats--a dose- response study. J Cancer Res Ther 2016;12:386-94.

62. Gunasekaran V, Elangovan K, Devaraj SN. Targeting hepatocellular carcinoma with piperine by radical-mediated mitochondrial pathway of apoptosis: An in vitro and in vivo study. Food Chem Toxicol 2017;105:106-18.

63. Choi EJ. Evaluation of equol function on anti-or prooxidant status in vivo. J Food Sci 2009;74:H65-71.

64. Stolzenberg-Solomon RZ, Sheffler-Collins S, Weinstein S, Garabrant DH, Mannisto S, Taylor P, et al. Vitamin e intake, alphatocopherol status, and pancreatic cancer in a cohort of male smokers. Am J Clin Nutr 2009;89:584-91.

65. Lin ZY, Chuang WL. Pharmacologic concentrations of ascorbic acid cause diverse influence on differential expressions of angiogenic chemokine genes in different hepatocellular carcinoma cell lines. Biomed Pharmacother 2010;64:348-51.

66. del Bello B, Paolicchi A, Comporti M, Pompella A, Maellaro E. Hydrogen peroxide produced during gamma-glutamyl transpeptidase activity is involved in prevention of apoptosis and maintainance of proliferation in u937 cells. FASEB J 1999;13:69-79.

67. Soo E, Thakur S, Qu Z, Jambhrunkar S, Parekh HS, Popat A. Enhancing delivery and cytotoxicity of resveratrol through a dual nanoencapsulation approach. J Colloid Interface Sci 2016;462:368-74.

68. Ganjam GK, Chi TF, Kietzmann T, Dimova EY. Resveratrol: Beneficial or not? Opposite effects of resveratrol on hypoxia-dependent pai-1 expression in tumour and primary cells. Thromb Haemost 2016;115:461-3

69. Do QD, Angkawijaya AE, Tran-Nguyen PL, Huynh LH, Soetaredjo FE, Ismadji S, et al. Effect of extraction solvent on total phenol content, total flavonoid content, and antioxidant activity of limnophila aromatica. J Food Drug Anal 2014;22:296-302. 